\title{
Ecosystem Services Provided by Grass-Legume Pastures $^{1}$
}

\author{
Jose Dubeux, Jr., Lynn Sollenberger, Mark Mauldin, and Liza Garcia²
}

\section{Introduction}

Ecosystem services are the benefits society obtains from ecosystems. These services benefit both people and the environment. Ecosystem services provided by grasslands include:

- products such as beef and milk (provisioning services)

- biological nitrogen $\left(\mathrm{N}_{2}\right)$ fixation (BNF)

- nutrient cycling (supporting ecosystem services)

- carbon sequestration and greenhouse gas mitigation

- water catchment and purification

- shade

- windbreaks

- habitat for pollinators and wildlife (regulating ecosystem services)

- cultural services (e.g., hunting, bird-watching) and aesthetic ecosystem services

\section{Grass-Legume Pastures and Ecosystem Services}

When legumes are integrated into grass pastures, the potential to provide ecosystem services in all of the aforementioned categories increases. Legumes can play a major role in mitigating the effects of climate change by: (1) lowering the emissions of the key greenhouse gases compared with $\mathrm{N}$-fertilized systems; (2) reducing the fossil energy used in the production of food and forage; and (3) contributing to the sequestration of $\mathrm{C}$ in soils (Jensen et al. 2012). Legumes are also able to fix atmospheric $\mathrm{N}_{2}$ by associating with soil bacteria (reducing $\mathrm{N}$ fertilizer inputs as a result), providing flowers for the pollinators upon which much of our food supply depends (Figure 1), and improving forage quality. In a research project conducted at the UF/IFAS North Florida Research and Education Center (UF/IFAS NFREC) in Marianna, FL, researchers identified 13 different bee species occurring in grass-legume pastures. Adding legumes might also increase primary productivity in low-input systems, with grass-legume mixtures outgrowing monocultures and enhancing nutrient cycling and soil organic matter accumulation.

In a recent harvest trial assessing seven rhizoma perennial peanut varieties at UF/IFAS NFREC, researchers measured the amount of atmospheric $\mathrm{N}_{2}$ these varieties could fix (Figure 2). They found variability among the varieties, but on average, the varieties fixed 180-200 lb N/acre/year and ranged from 110-250 lb N/acre/year (Dubeux, Jr. et al. 2017). UF Peace, UF Tito, and Arbrook ranked highest among the varieties (Figure 2). If the peanut appears in a grazed grass-legume mixture, this fixation is expected to be lower due to reduced participation of rhizoma perennial

1. This document is SS-AGR-423, one of a series of the Agronomy Department, UF/IFAS Extension. Data presented in this EDIS document originated from a project supported by the National Institute of Food and Agriculture, USDA, under Award no. 2016-67019-24990. Original publication date October 2018. Visit the EDIS website at https://edis.ifas.ufl.edu for the currently supported version of this publication.

2. Jose Dubeux, Jr., associate professor, Agronomy Department, UF/IFAS North Florida Research and Education Center; Lynn Sollenberger, distinguished professor, Agronomy Department; Mark Mauldin, Extension agent I, UF/IFAS Extension Washington County; and Liza Garcia, graduate student, Agronomy Department, UF/IFAS NFREC; UF/IFAS Extension, Gainesville, FL 32611.

The Institute of Food and Agricultural Sciences (IFAS) is an Equal Opportunity Institution authorized to provide research, educational information and other services only to individuals and institutions that function with non-discrimination with respect to race, creed, color, religion, age, disability, sex, sexual orientation, marital status, national origin, political opinions or affiliations. For more information on obtaining other UF/IFAS Extension publications, contact your county's UF/IFAS Extension office. 
peanut in the botanical composition of the pasture (Santos et al. 2018) and frequent defoliation from cattle. However, it is still a more sustainable system compared to grass monocultures.

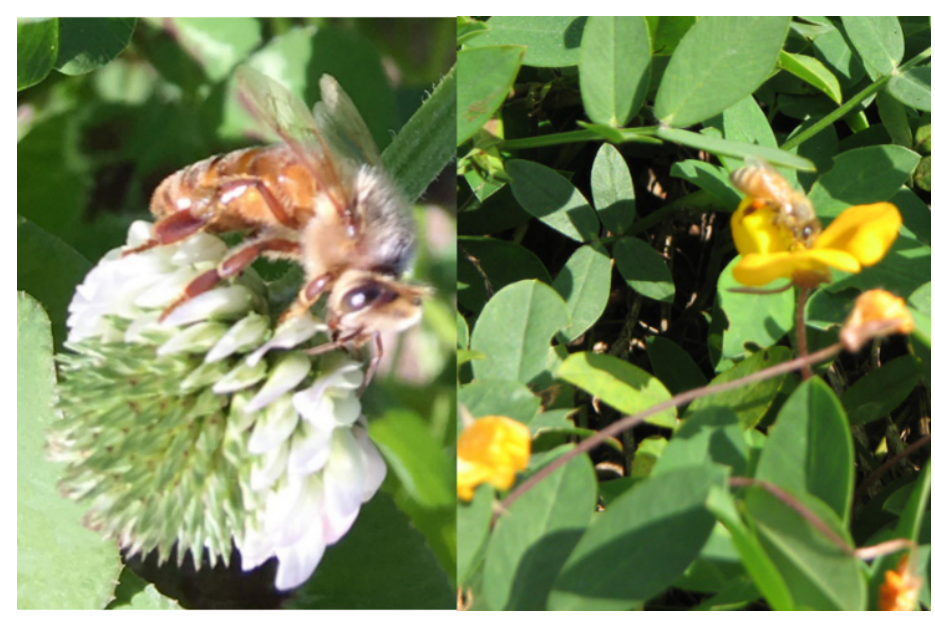

Figure 1. Honeybee on white clover flower in Citra, FL (left) and rhizoma peanut (Arachis glabrata Benth.) flower in Marianna, FL (right). Credits: Jose Dubeux, Jr., UF/IFAS

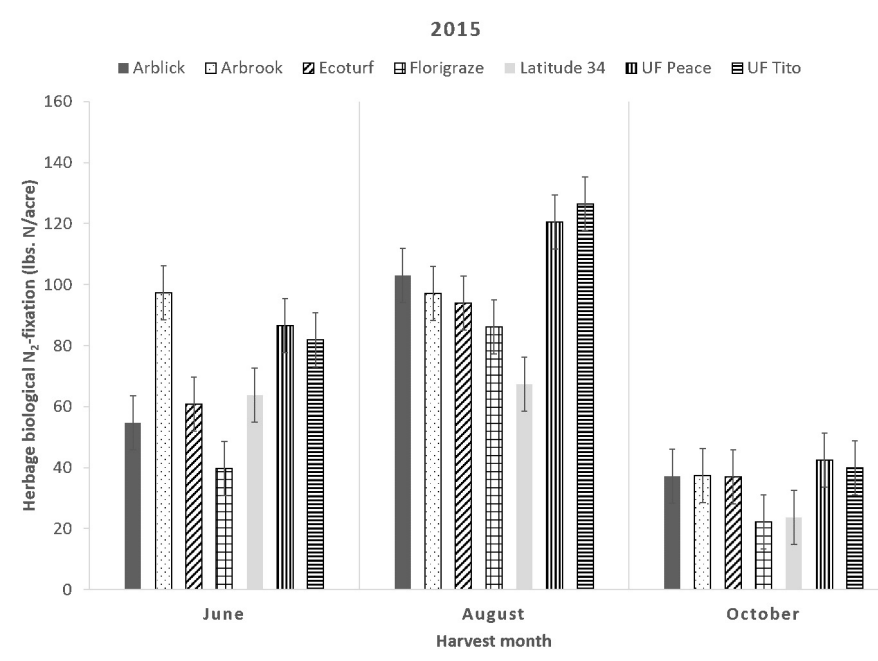

Figure 2. Biological $\mathrm{N}_{2}$ fixation by rhizoma perennial peanut varieties in north Florida. Adapted from Dubeux, Jr. et al. (2017). Credits: UF/IFAS

Forage legumes are more digestible and have greater crude protein than grasses. Grazing on grass-legume pastures instead of grass monocultures often results in greater livestock performance. Research has been conducted at UF/ IFAS NFREC in Marianna to assess animal performance when grazing $\mathrm{N}$-fertilized grasses or grass-legume systems. The grass-legume systems consisted of bahiagrass (Paspalum notatum Flügge)-rhizoma peanut pastures in the summer and overseeded cool-season grasses (rye and oat) plus clovers (crimson, red, and ball) in the winter (Figure $3)$.
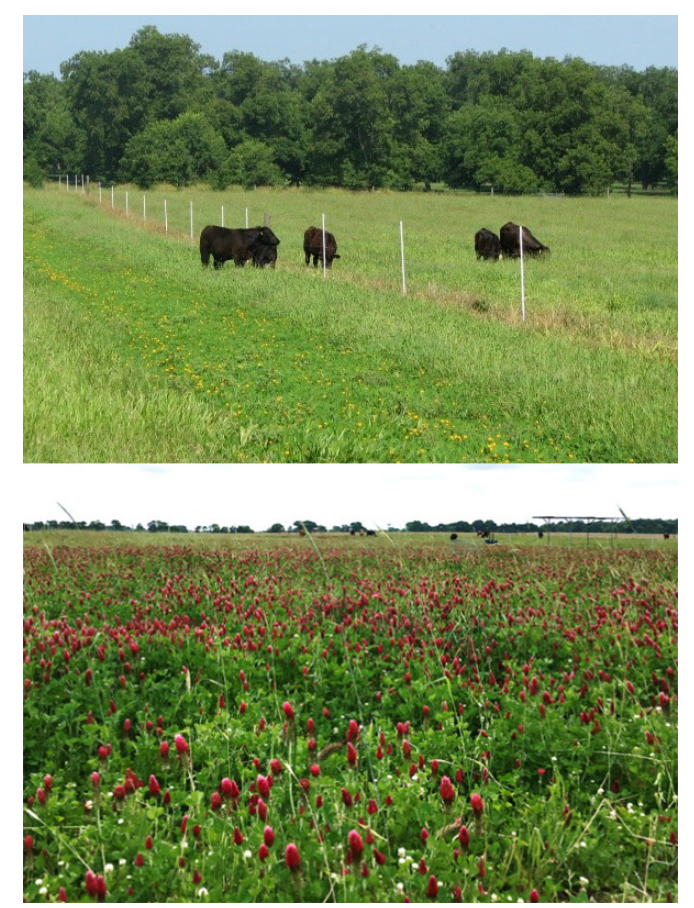

Figure 3. Grass-legume pastures in Marianna, FL. On the top, warmseason mixture with Argentine bahiagrass and Ecoturf rhizoma peanut; on the bottom, cool-season mixture with cool-season grasses and clovers.

Credits: Jose Dubeux, Jr., UF/IFAS

Results from the grazing trial indicate that it is possible to reduce $\mathrm{N}$ fertilization from $200 \mathrm{lb}$ N/acre/year to $30 \mathrm{lb} \mathrm{N} /$ acre/year when legumes are integrated into the system. The grass-legume system produced $70 \mathrm{lb}$ more livestock gain using only $15 \%$ of the $\mathrm{N}$ fertilizer that the grass system used (Table 1). This demonstrates the viability of adding legumes to replace $\mathrm{N}$ fertilizer, resulting in greater livestock gains and reduced environmental impact.

\section{Conclusion}

Grasslands produce far more than beef and milk. They provide ecosystem services that benefit people and the environment. Integrating forage legumes into grasslands enhances their capacity to provide ecosystem services, including $\mathrm{C}$ sequestration, habitat for wildlife and pollinators, water catchment and purification, and nutrient cycling. Results from a three-year study indicate the possibility to produce similar (or greater) livestock gains in grass-legume pastures that use only $15 \%$ as much $\mathrm{N}$ fertilizer as grass monocultures. Livestock producers and the general public could greatly benefit from policy designed to help establish grass-legume systems in farms and to pay for ecosystem services provided by grasslands. 


\section{References}

Dubeux, Jr., J. C. B., A. R. S. Blount, C. Mackowiak, E. R. S. Santos, J. D. Pereira Neto, U. Riveros, L. Garcia, D. M. Jaramillo, and M. Ruiz-Moreno. 2017. "Biological $N_{2}$ fixation, belowground responses, and forage potential of rhizoma peanut cultivars." Crop Sci. 57: 1027-1038.

Dubeux, Jr., J. C. B., L. Garcia, N. DiLorenzo, C. Prevatt, A. Blount, C. Mackowiak, E. Santos, D. Jaramillo, and M. RuizMoreno. 2016. "Reduce your N fertilizer cost and maintain cattle productivity by planting forage legumes." The Florida Cattleman and Livestock Journal 81(3): 94-97.

Jensen, E. S., M. B. Peoples, R. M. Boddey, P. M. Gresshoff, H. Hauggaard-Nielsen, B. J. R. Alves, and M. J. Morrison. 2012. "Legumes for mitigation of climate change and the provision of feedstock for biofuels and biorefineries. A review." Agronomy for Sustainable Development 32: 329-364.

Millennium Ecosystem Assessment. 2005. Ecosystems and Human Well-Being: Synthesis. Washington, D.C.: Island Press.

Santos, E. R. S., J. C. B. Dubeux, Jr., L. E. Sollenberger, A. R. S. Blount, C. Mackowiak, N. DiLorenzo, D. M. Jaramillo, L. Garcia, T. P. Pereira, and M. Ruiz-Moreno. 2018. "Herbage responses and biological $\mathrm{N}_{2}$-fixation of bahiagrass and rhizoma peanut monocultures compared with their binary mixtures." Crop Sci. 58: 1-15. doi: 10.2135/ cropsci2018.02.0128.

Table 1. Animal performance on different grazing systems in Marianna, FL. Average of 2016-2017 grazing seasons.

\begin{tabular}{|c|c|c|c|}
\hline Pasture Type & Stocking Rate (steers/acre) & $\begin{array}{l}\text { Average Daily Gain (lb/head/ } \\
\text { day) }\end{array}$ & Gain per Acre (lb/acre/year) \\
\hline BG & 1.42 & 1.11 & 429 \\
\hline BGN & 1.54 & 1.12 & 436 \\
\hline BG-RPP & 1.30 & 1.40 & 501 \\
\hline \multicolumn{4}{|c|}{$\begin{array}{l}\text { BG }=\text { unfertilized (-N) Argentine bahiagrass overseeded with rye/oat + crimson/red/ball clovers + } 30 \mathrm{lb} \text { N/acre/year. } \\
\text { BGN = fertilized Argentine bahiagrass ( } 100 \mathrm{lb} N / \text { acre/year) overseeded with rye/oat }+100 \mathrm{lb} N / \text { acre/year (annual N fertilization of } 200 \mathrm{lb} \mathrm{N} / \\
\text { acre). } \\
\text { BG-RPP = unfertilized (-N) Argentine bahiagrass strip-planted with Ecoturf rhizoma peanut, overseeded with rye/oat + crimson/red/ball } \\
\text { clovers }+30 \mathrm{lb} \text { N/acre/year. }\end{array}$} \\
\hline
\end{tabular}

